\title{
Makna Profesi Pembatik Pada Kelompok Seraci Batik Betawi Di Kabupaten Bekasi
}

\author{
${ }^{1}$ Nurul Fauziah, ${ }^{2}$ Wa Ode Sitti Nurhaliza \\ 1 Universitas Bhayangkara Jakarta Raya \\ 2Universitas Bhayangkara Jakarta Raya \\ E-mail: ${ }^{1}$ nurul.fauziah@dsn.ubharajaya.ac.id, ${ }^{2}$ wa.ode@dsn.ubharajaya.ac.id
}

\begin{abstract}
Abstrak. Penelitian ini fokus pada Kelompok Seraci Batik Betawi secara aktif memproduksi batik betawi dengan berbagai corak dan motif khas budaya Betawi. Mereka yang memilih profesi pembatik memiliki tingkat ketekunan dan kejelihan yang tinggi disebabkan dalam membatik dibutuhkan kesabaran serta ketelitian. Penelitian ini membahas 10 orang pembatik tradisional di kelompok Seraci Batik Betawi. Melalui penelitian ini diharapkan memahami dan mendeskripsikan latarbelakang orang-orang yang memilih menekuni profesi pembatik. Penelitian ini menggunakan pendekatan Fenomenologi. Teknik pengumpulan data dilakukan melalui wawancara mendalam dan pengamatan partisipatif berdasarkan perpektif tindakan sosial. Hasil penelitian menunjukkan bahwa terdapat dua motif yang melatbelakangi sesorang menjadi pembatik. Pertama, motif sebab yaitu pengalaman komunikasi dialami pada masa lalu sebagai kegemaran menggambar, aktualisasi diri, kegiatan tambahan dan adanya dukungan dari keluarga. Kedua, motif tujuan yaitu adanya keinginan untuk melestarikan batik betawi, mempromosikan budaya betawi, menunjukkan kemampuan, merasa bangga terhadap diri sendiri dan menambah penghasilan.
\end{abstract}

\section{Kata Kunci: Pembatik, Motif, Pengalaman}

Abstract. This study focuses on the Seraci Batik Betawi Group actively producing Betawi batik with various patterns and motifs typical of Betawi culture. Those who choose the profession of batik have a high level of perseverance and ugliness due to batik required patience and thoroughness. This study discusses ten traditional batik people in the Seraci Batik Betawi group. Through this research, it is expected to help understand and describe the background of people who choose to pursue the batik profession. This study uses the Phenomenology approach. Data collection techniques are carried out through in-depth interviews and participatory observation based on the perspective of social action. The results showed that there were two motives behind someone becoming a batik. First, the motive for that is the experience of communication experienced in the past as drawing hobbies, self-actualisation, additional activities and the support of the family. Second, the motive of the goal is the desire to preserve Betawi batik, promote Betawi culture, demonstrate ability, feel proud of themselves and increase income.

Keywords: Batik, Motives, Experience 


\section{Latar Belakang}

Mengkaji tentang proses pembuatan batik, pemasaran batik juga tidak terlepas dari peranan pembuat batik atau pengrajin batik itu sendiri. Tanpa pembuat batik, karya seni (batik) tidak akan diproduksi dan juga tidak akan menjadi ikon negara Indonesia. Mereka yang memilih profesi pembatik memiliki tingkat ketekunan dan kejelihatn yang tinggi disebabkan dalam membatik dibutuhkan kesabaran serta ketelitian. Banyak diantara pembuat batik tradisional rata-rata perempuan yang juga kesehariannya berperan sebagai ibu rumah tangga.

Dalam hal berbusana batik menjadi bagian dari gaya hidup masyarakat Indonesia. Batik merupakan salah satu warisan kekayaan budaya Indonesia yang mendunia dan telah mendapat pengakuan dari UNESCO. Untuk memperingatinya, Indonesia menetapkan tanggal 2 Oktober sebagai Hari Batik Nasional. Keberadaan Batik saat ini menjadi keunggulan dan nilai jual tersebut bagi bangsa Indonesia di mata dunia. Beberapa daerah yang ada di Indonesi memiliki kerajinan Batik dengan berbagai corak dan motif khasnya masingmasing. Ibu kota Jakarta yang menjadi pusat kebudayaan Betawi juga memiliki kekhasan corak kain batik disebut batik Betawi. Pengrajin Batik Betawi tersebar dibeberapa daerah Jabodetabek (Jakarta, Bogor, Depok, Bekasi). Salah satu lokasi pengrajin Bati Betawi yakni kelompok Batik Seraci yang terletak di Kecamatan Tarumajaya kabupatan Bekasi. Kekhasan batik betawi juga tidak kalah dengan batik-batik dari Solo dan Jogjakarta.

Kelompok Seraci Batik Betawi secara aktif memproduksi batik betawi dengan berbagai corak dan motif khas budaya Betawi. Proses produksi yang dilakukan setiap hari. Dalam kurung waktu satu bulan, kelompok pengarajin batik ini dapat menghasilkan 100-200 potong batik cap dan 5 potong batik tulis. Produk batik Betawi ini telah dipasarkan di Jakarta, Bekasi dan Bandung. Ketiga daerah ini menjadi target utama dalam pemsarana Batik Betawi produksi kelompok Batik Seraci. Kelompok Batik Seraci melibatkan ibu-ibu sebagai tenaga kerja yang memiliki kemampuan dalam membatik.

Para pengrajin batik betawai di kelompok seraci batik betawi berjumlah 10 orang yang terdiri dari 2 orang pembuat batik cetak dan 8 orang pembuat batik menggunakan alat tradisional. Mereka yang berprofesi sebagai pembatik memiliki kemampuan menggambar yang baik, dan juga telaten dalam menyelesaikan desain-desain batik yang mereka produksi.

Seni kerajinan batik termasuk indutsri rumah tangga atau industri kecil. Industri skala kecil di Indonesia merupaka bahan yang menarik untuk terus dibahas dan merupakan perhatian pemerintah karena keberadaanya mampunyai arti penting baik secara ekonomi maupun politik. Pembangunan industry kecil dan menengah termasuk industri kerajinan serta industri rumah tangga, didorong dan dibina menjadi usaha yang semakin berkembang dan efisiensi sehingga mampu mandiri dan menambah pendapatan masyarakat. 
Usaha kerajinan yang mengahasilkan karya yang bernilai senin ternyata mampu menghantarkan suatu daerah memiliki popularitas yang cukup tinggi dan memberi ciri khas terhadap daerah tersebut melalui penampilan karya masyarakat daerah itu.

Hasil observasi awal yang peneliti lakukan di kelompok Seraci Batik Betawi menunjukkan bahwa para pembuat batik menghasbiskan waktunya sejak pukul 8 pagi hingga 4 sore mejalani aktifitas sebagai pembuat batik. Banyak diantara pembuat batik di Seraci Batik betawi adalah ibu rumah dan juga ada beberapa remaja yang menekuni profesi sebagai pembatik. Ketertarikan mereka untuk bergabung dan menekuni profesi ini disebabkan oleh banyak hal, diantaranya kegemaran menggambar, wujud kecintaan terhadap warisan leluhur kita.

Ditambah lagi, rutinitas pekerjaan sebagai pembatik di kelompok seraci batik betawi menuntut para pembatik harus rajin dan telaten dalam menyelesaiakn setiap desan-desain batik mulai dari proses menggambar, mewarnai hingga batik tersebut siap dipasarkan. Hal ini tentu bukanlah perkara muda, mengingat tidak semua orang mau menekuni profesi pembatik. Dunia perbatikan selalu menarik untuk dikaji apalagi menyangkut para pembuat batik.

Berdasarkan fenomena-fenomena di atas, peneliti tertarik untuk mengkaji lebih mendalam mengenai makna profesi pembatik pada kelompok batik betwai, dalam hal ini peneliti akan fokus pada tindakan in order motive, yang merujuk pada masa yang akan datang dan tindakan because motive yang merujuk pada masa lalu. Artinya peneliti akan melihat alasan para pembatik betawi memilih untuk menekuni profesi pembatik dan juga tujuan mereka memilih menjadi profesi pembatik.

Berdasarkan uraian latar belakang di atas, penelitian ini fokus pada makna profesi pembatik Betawi pada Kelompok Seraci Batik Betawi di Kabupaten Bekasi. Penelitian ini akan mengkaji secara mendalam motif./alasan memilih menekuni dunia pembatik dan tujuan menjadi pembatik bagi para pembatik Betawi di Kelompok Seraci Batik Betawi di Kota Bekasi. Penelitian ini bertujuan untuk menganalisis makna profesi pembatik Betwai di Kelompok Seraci Batik Betawi di Kota Bekasi.

\section{Tinjuan Pustaka}

\section{Konsep Batik}

Batik merupakan budaya yang telah lama berkembang dan dikenal oleh amsyarakat Indonesia. Kain yang sudah digambar dengan menggunakan malam kemudian diberi warna dengan cara pencelupan, setelah itu malam dihilangkan dengan cara merebus kain, akhirnya dihasilkan sehelai kain yang 
disebut batik serupa beragam motif yang mempunyai sifat-sifat khusus (Indonesia.gunadarma.ac.id.2015).

Sejarah batik memang dominan di pulau Jawa mengingat pulau ini memiliki tingkat kepadatan penduduk yang tinggi sejak dahulu kala bahkan sampai sekarang. Karena tingkat kepadatan penduduk inilah, tercatat dalam sejarah bahwa di pulau Jawa terdapat banyak kerajaan. Kreatifitas seni batik ini tidak hanya berkutat pada budaya lokal atau budaya Jawa saja, akan tetapi juga bertemu dengan budaya luar seiring sejalan dnegan ramainya jalinan perdagangan antar Negara. Kebudayaan Jawa yang bersentuhan dengan budaya lainnya seperti dalam hal perdangangan dengan Cina, India dan Timur Tengah memberi warna tersendiri dalam ragam motifnya. Popularitas batik mulai meningkat pada kahir abad ke-18 atau awal abad ke-19. Munculnya batik cap menandai era industrialisasi. Selain itu, sejak industrialisasi dan globalisasi yang memperkenalkan teknik otomatisasi, batik jenis baru muncul yaitu batik printing (Iskandar \& Eny: 2017).

\section{Teori Tindakan Sosial}

Teori tindakan sosial Max Weber berorientasi pada motif dan tujuan pelaku. Teori ini membantu kita memahami perilaku individu maupun kelompok bahwa masing-masing memiliki motif tujuan berbeda terhadap sebuah tindakan yang dilakukan. Teori ini digunakan untuk memahami tipetipe perilaku setiap individu maupun kelompok. Dengan memahami perilaku setiap individu maupun kelompok, sama halnya kita telah menghargai dan memahami alasan-alasan mereka dalam melakukan suatu tindakan. Sebagaimana diungkapkan Weber, cara terbaik untuk memahami berbagai kelompok adalah menghargai bentuk-bentuk tipikal yang menjadi ciri khasnya. Sehingga kita dapat memahami alasan-alasan mengapa warga masyarakat tersebut bertindak (Saifuddin, 2013: 115).

Terdapat beberapa klasisikasi tipe tindakan yakni (1) tindakan Tradisional, yaotu tindakan yang ditentukan oleh kebiasaan-kebiasaan yang sudah mengakar secara turun temurun. (2) Tindakan afektif, merupakan tindakan yang ditentukan oleh kondisi-kondisi dan orientasi-orientasi smeosinal si aktor. (3) Rasionalitas instrumental, merupakan tindakan yang ditunjukan pada pencapaian tujuan-tujuan yang secara rasional diperhitungkan dan diupayakan sendiri oleh aktor yang bersangkutan. (Turner,.S, 2012:115).

\section{Teori Fenomenologi}

Konsep fenomenologi yang dikembangkan oleh Alfred Schtuz biasa diistilahkan dengan fenomenologi sosial. Pemikiran Schutz tentang fenomenologi sosial merupakan gabungan fenomenologi yang telah dicetuskan oleh Hurssel dan juga mengintegrasikan dengan konsep tindakan sosial Weber. Schutz adalah tokoh fenomenologi pertama yang meletakkan dasar-dasar fenomenologi bagi ilmu sosial. Schutz sendiri tidak pernah menjadi murid Husserl. Kedekatan Schutz dengan Husserl hanyalah sebatas melakukan 
diskusi-diskusi terkait fenomenologi yang dilakukan keduanya. Schutz berusaha menyusun konsep fenomenologi Husserl dan mengoperasionalkannya agar lebih daoat diaplikasikan dalam kajian ilmu sosial.

Fenomenologi yang diususn Husserl dioperasionalisasikan oleh Schutz agar lebih mudah dipahami. Konsep fenomenologi Husserl memang memiliki kesan yang lebih abstrak, dan Schutz menyusun fenomenologi menjadi konseo yang lebih praktis. Bagi Schutz, tugas fenimenologi adalah menghubungkan antar pengetahuan ilmiah dengan pengalaman sehari-hari dan dari kegiatan dimana pengalaman dan pengetahuan itu berasal (Kuswarno, 2009: 17).

Bagi Schutz, kesadaran yang diartikan Husserl sebagai kesadaran internal individu, merupakan kesadaran sosial. Dalam pandangan Schutz, manusia adalah makhluk sosial, sehingga kesadaran akan dunia kehidupan sehari-hari adalah sebuah kesadaran sosial. Fenomenologi Schutz berbiacara dunia intersubjektif. Dunia individu merupakan dunia intersubjektif, dengan makna beragam dan perasaan sebagai bagian dari kelompok. Terdapat tuntutan bagi individu untuk memiliki pemahaman satu sama lain dengan individu lain dan bertindak dalam kenyataan yang sama. Dengan demikian, ada penerimaan timbal balik, pemahaman atas dasar pengalaman bersama, dan tipikasi atas dunia bersama. Melalui tipikasi inilai manusia belajar menyesuaikan diri ke dalam dunia yang lebih luas, juga dengan melihat diri kita sendiri sebagai orang yang memainkan peran dalam situasi tipikal (Kuswarno, 2009 : 18).

Pemikiran Schutz mengenai fenomenologi dipengaruhi tokoh Edmun Husserl dan Max Weber dengan teori tindakan sosial. Sehingga Schutz memandang keseharian sosial sebagai sesuatu yang intersubjektif. Setiap inidvidu melakukan tindakan memiliki keunikan tersendiri. Masing-masing individu mempunyai motif dan makna disetiap tindakan subjektifnya. Motif yang ada dalam diri individu menyatuh dalam makna ketika individu tersebut bertindak. Motif ini bukan bagian terpisah, melainkan motif terintegrasi kedalam sebuah sistem dan bersifat konsisten. Untuk mendeskripsi keseluruhan tindakan individu bisa dilihat dari tindakan "because of motive," motif sebab merujuk pada masa lalu dan tindakan "in-order-to-motif," motif tujuan merujuk pada masa depan. Sebuah fenomena dianggap tampilan suatu objek, kejadian atau kondisi dalam persepsi. Pada esensi pengalaman pembatik mengenai motid melatarbelakangi memiliki profesi sebagai pembatik. Sehingga realitas dalam fenomenologi sebagai cara bagaimana hgal-hal tampak dalam perspesi sadar dari pembatik betawi. Hal ini sejalan dengan yang dikatakan Schutz bahwa tugas fenomenologi adalah menghubungkan antara pengetahuan ilmiah dengan pengalaman sehari-hari dan dari kegiatan tindakan dimana pengalaman dan pengetahuan itu berasal. Dalam pemahaman Schutz dunia sosial diinterpretasikan berdasarkan kategori akal sehat dan dikontruksi yangh bersumber dari dunia sosial. Dengan demikian, manusia sebagai makhluk 
sosial tidak terlepas dari pemberian makna terhadap hal-hal yang ditemukan dan di lakukan dalam keseharian.

\section{Metodologi Penelitian}

\section{Paradigma Penelitian}

Pendekatan yang digunakan dalam penelitian ini adalah pendekatan kualitatif karena penelitian ini berusaha untuk menganalisis makna profesi pembatik betawi di kabupaten Bekasi. Penelitin ini menggunakan paradigm konstrukstivis sebagau akar pijak. Filosofinya yang secara ontologis disebut sebagai relativisme, yaitu realitas yang dikontruksi secara lokal dan spesifik (Denzin \& Lincoln, 2009: 135). Paradigm kontruktivis mengacu pada kontruktivisme, yakni filsafat pengetahuan yang meyakini bahwa pengetahuan menuasia merupakan hasil kontruksi yang dibentuk oleh manusia itu sendiri. Menurut paradigm konstruktivi, realitas merupakan konstruksi sosial yang diciptakan oleh individu. Individu adalah manusia bebas yang melakukan hubungan satu samal lain. Individu menjadi penentu dalam dunia sosial yang dikonstruksi berdasarkan kehendaknya.

\section{Metode Penelitian}

Penelitian ini menggunakan metode fenimenologi untuk membantu peneliti dalam memasuki sudut pandang orang lain dan berupaya memahami alasan dan motif mereka dalam melakukan sesuatu. Fenomenologi berasal dari filosofi Husserl (1859-1938), sedangkan dasar penerapannya bersumber dari Alfred Schutz (1899-1939). Metode fenomenologi tepat digunakan dalam penelitian ini karena peneliti berusaha menganalisis dan memahami makna profesi pembatik betawi yang akan terfokus pada in order motive, yang merujuk pada masa yang akan datang dan tindakan because motive yang merujuk pada masa lalu. Artinya peneliti akan melihat alasan para pembatik betawi memilih untuk menekuni profesi pembatik dan juga tujuan mereka memilih menjadi pembatik. Bahkan Creswell mengungkapkan bahwa tradisi fenomenologi adalah adalah " a study describe the meaning of the lived experiences for several individuals about a conceps or the phenomenon" (Cresswell, 1997: 51). Sementara itu, Littlejohn menyebutkan bahwa tradisi fenomenologi fokus pada pengalaman sadar seseorang. Individu secara aktif mengintrepretasikan pengalaman mereka dan memahami kehidupan melalui pengalaman pribadi (Littlejohn, 2005: 38).

\section{Lokasi Penelitian}

Penelitian ini dilakukan di kecamatan Tarumajaya, kabupaten Bekasi yakni pada kelompok pengrajin batik bekasi yakni Batik Seraci Betawi. 


\section{Teknik Penentuan Informan}

Penelitian ini melibatkan 10 orang pengrajin Batik Betwai yang terdiri dari 2 orang laki-laki sebagai pengarajin batik cap dan 8 orang perempuan sebagai pengrajib batik menggunakan cara tradisional. Pemilihan dan penentuan informan dilakukan secara purposive sampling yakni berdasarkan kriteria yang telah ditentukan oleh peneliti. Teknik penentuan informan ini digunakan berdasarkan pertimbangan dan tujuan tertentu dengan memenuhi beberapa kriteria yang telah ditetapkan yakni: (1) Mempunyai pengetahuan dan pengalaman tentang isu atau topik penelitian, (2) Mempunyai kemampuan untuk merefleksikan dan mengartikulasikan pengalaman tersebut, (3) Bersedia menjadi partisipan dalam penelitian, (4) Mempunyai waktu untuk wawancara dan bersedia diobservasi.

\section{Teknik Pengumpulan Data}

Aktifitas pengumpulan data yang peneliti lakukan mengacu pada aktivitas pengumpulan data dari Cresswell, yaitu "a data collection circle" (Kuswarno, 2009: 13). Aktivitas yang dilakukan dengan model Cresswell memperlihtakan bahwa satu sama lain saling berhubungan, diawali dengan penentuan tempat atau individu. Teknik pengumpulan data yakni observasi langsung, wawancara mendalam dan studi dokumentasi. Dalam penelitian ini, teknik pengumpulan data yang digunakan adalah wawancara mendalam, observasi dan studi dokumentasi.

Wawancara bertujuan untuk menemukan dan membuka tabir tentang apa yang ada didalam pemikiran seseorang sehingga teknik ini sesuai dengan fenomenologi yang berusaha untuk mengatahui makna profesi pembatik betawi yang akan terfokus pada in order motive, yang merujuk pada masala yang akan datang dan tindakan because motive yang merujuk pada masa lalu. Adapun jenis wawancara mendalam yang digunakan dalam penelitian ini adalah wawancara mendalam semi-terstruktur, yang berarti bahwa peneliti mempunyai pedoman wawancara yang digunakan sebagai panduan untuk melakukan wawancara dengan informan, namun peneliti dapat mengembangkan pertanyaan tersebut diluar daftar pertanyaan yang telah disusun selama pertaynaan tersebit relevan dengan permasalahan yang diteliti (Sugiyono, 2013: 233).

Teknik selanjutnya diugunakan dalam pengumpulan data fenomenologi adalah observasi, observasi dilakukan karena ucapan, perkataan atau jawaban narasumber bisa dimanipulasi atau berubah-ubah tergantung pada kondisi atau lingkungan narasumber, sehingga perlu dilakukan crosscheck dengan melihat dan mengamati narasumber. Dalam obsercasi partisipatisi pasif (Sugyono, 2013: 227), peneliti hanya datang ditempat kegiatan yakni tempat berlangsungnya proses pembuatan batik betawi. Studi dokumentasi berupa hasil-hasil penelitian sebelumnya, foto, video terkait objek penelitian. Sebagai penguat asumsi yang dapat menjadi landasan teori penelitian ini. Studi 
kepustakaan bertujuan untuk memberikan dasar teoritis bagi sebuah penelitian (Rakhmat, 2000: 107).

\section{Teknik Analisis Data}

Teknik analisis data dalam penelitian yang menggunakan metode penelitian kualitatif mencakup tiga komponen utama,. Miles dan Huberman (1984 \& 1994, dalam Denzin \& Lincoln, 2009 :129) menuliskan bahwa analisis data terdiri dati tiga sub proses yang saling terkait; reduksi data, penyajian data dan pengambilan keputusan/verifikasi. Keseluruhan proses itu dilakukan sebelum tahap pengumpulan data hingga setelah tahap pengumpulan data akhir.

Reduksi data adalah komponen pertama yang digunakan untuk mengalisas data. Proses reduksi data dimulai sebelum pelaksanaaan pengumpulan data hingga laporan akhir penelitian selesai disusun. Reduksi data dalam penelitian ini berfungsi untuk tetap menjaga data yang disajikan dan dianalisis tetap fokus pada tujuan dan pertanyaan penelitian. Komponen kedua dalam teknik analisis data dalah sajian data. Sutopo (2002; 92) sajian data dilakukan ketika peneliti menyusun dan menulis hasil penelitian. Data yang disaring, data yang dianggap sesuai dengan tujuan penelitian dan menjawab pertanyaan penelitian sehingga data menjadi fokus dalam menjawab masalah, disajikan salam bentuk naratif deskripstif. Sajian data yang lengkap dan mendalam akan memudahkan proses analisis, pengkajian, dan pembahasan penelitian sehingga membuat sajian data menjadi lebih mendalam. Penarikan kesimpulan dan verifikasi adalah komponen ketiga dalam teknik analisis data.

\section{Teknik Keabsahan Data}

Beberapa peneliti kualitatfi telah menggunakan alat kuru untuk menyajikan keabsahan data dari penelitian kulaitatif melalui empat kriteria keterpercayaan. Kriteria tersebut adalah : (1) Credibility (derajat kepercayaan); (2) Transferability (keteralihan); (3) Dependability (ketergantungan); dan (4) Confirmability (kepastian). Adapun teknik validitas penelitian yang digunakan dalam penelitian ini meliputi: (1) perpanjangan pengamatan, menurut (Sugyono, 2013: 235) perpanjangan pengamatan dilakukan untuk mengecek kembali apakah data yang telah diberikan oleh sumber data selama ini merupakan data yang sudah benar atau tidak; (2) Triangulasi Sumber Data.

\section{Hasil dan Pembahasan}

Sejak batik dinobatkan sebagai warisan budaya dunia oleh UNESCO, batik dapat dikatrakan bukan hanya sekedar kain biasa yang memiliki berbagai gambar. Batik bahkan sudah menjadi bagian dari gaya hidup masyarakat Indonesia khususnya dalam hal berbusaha. Salah satu batik yang cukup dikenal dikalangan masyarakat yakni batik Betawi. Batik Betawi merupakan warisan budaya dari etnik Betwai yang terdapat didaerah ibu kota Jakarta. 
Kerajinan Batik Betawi mulai telah ada dibeberapa lokasi, salah satunya di Kabupaten Bekasi. Seraci Batik Betawi merupakan sebuah kelompok pengrajin Batik Betawi yang berada di bawah binaan PLTGU Muara Bekasi.

Mengkaji tentang batik tentu berkaitan dengan orang-orang yang berkecimpung di dunia perbatikan. Mereka yang berprofesi sebagai pembatik tentu memiliki kemampuan yang luar biasa untuk mengahsilkan gambar/lukisan yang terdapat di setiap kain batiknya. Pembatik di Seraci Batik yang terdiri dari 10 orang pembatik yang rata-rata ibu rumah tangga yang berusia 30-40 tahun dan juga terdapat beberapa anak gadis yang berusia 16-23 tahun. Pembatik di kelompok Seraci Betawi dominan sebagai pembatik tradisional dimana mereka menggambarkan batik menggunakan alat tradisional. Mereka sebelum menjadi pembatik awalnya mengikuti pelatihanpelatihan batik yang diadakan disekitar pemukimannya.

Berdasarkan hasil peneltiian yang diperoleh peneliti menunjukkan bahwa, mereka yang menekuni profesi sebagai pembatik di Seraci Batik Betawi umumnya memiliki ketekunana dan ketelatenan yang sangat tinggi. Tuntutan pekerjaan sebagai pembatik mengharuskan mereka untuk menggambar setiap motif-motif batik di kain, lalu menggunakan tindak untuk mewarnai dan melewati berbagai proses yang panjang. Memang, tidak bias dipungkiri bahwa hal yang perlu dimiliki sebagai seorang pembatik adalah kesabaran, ketelitian dan ketekunana dalam mengahsilkan setiap kain-kain batiknya.

Keputusan untuk memilih profesi sebagai pembatik tentu bukanlah hal yang mudah. Hal ini berproses kedalam lingkungan sosial masyarakat para pembatik di seraci Batik Betawi. Sebagian besar mereka yang bekerja sebagai pembatik berada dalam satu lingkungan (kecamatan) sehingga proses komunikasi dan interkasi yang terjadi seputar dunia batik. Ini menunjukkan bahwa setiap individu dalam memilih atau menetukan apa yang hendak dikerjakan dan yang tidak dikerjakan juga tergantung pada bagaimana keseharian sosial, lingkungan masyarakat mereka berada dan dengan siapa mereka terlibat komunikasi setiap harinya. Untuk memuruskan untuk menjadi pembatik tentu setiap individu memiliki alasan dan tujuan ketika bertindak. Hal ini sejalan dengan pendapat Schutz yang memandang keseharian sosial sebagai sesuatu yang intersubjektif.

Masing-masing individu mempunyai motif dan makna disetiap tindakan subjektifnya. Motif yang ada dalam diri individu menyatuh dalam makna ketika individu tersebut bertindak. Motif ini bukan bagian terpisah, melainkan motif terintegrasi kedalam sebuah sistem dan bersifat konsisten. Dalam menggambarkan tindakan setipa indvidu dapat dilihat dari tindakan "because of motive" artinya motif sebab yang merujuk pada masa lalu dan tindakan "in order to motive", motif tujuan. Pada setiap tindakan individu, terdapat motif menjadi orientasi dari tindakanya. Menurut Max Weber, makna dan motif inilai berhubung langsung dengan tindakan manusia (Mulyana, 2006:61). Motif penting dalam melihat diri individu yang melatarbelakangi memilih profesi 
sebagai pembatik di Seraci Batik Betawi sebagai tempat bekerja, karena motif dapat melihat diri pembatik dan tindakan "because of motive" dan tindakan "in-order-to-motive" dalam Fenomenologi Schutz.

\section{Motif Sebab Memilih Profesi Pembatik}

Motif sebab (in order motive) yang mendorong dan melatarbelakangi individu untuk mengambil tindakan menjadi pembatik cukup beragam. Keberagaman orientasi dimiliki, dilatarbelakangi oleh berbagai aspek pengalaman komunikasi yang mengkonstruksi dirinya memilih profesi pembatik. Ditambah lagi lingkungan sosial dimana mereka berada turut mendukung motif-motif sebab mereka memilih menjadi pembatik.

a. Kegemaran Menggambar

Setiap individu tentu memiliki cara tersendiri dalam mengembangkan dan menyalurkan hobinya. Tak terkecuali bagi inidvidu yang memiliki ketertarikan dalam seni lukis dan gambar. Hal ini dapat dikatarakan bahwa "kebiasaan bertindak" menjadi bagian dari hobi. Profesi pembatik tentu bukanlah hal mudah, dibutuhkan tingkat kesabaran, ketelitian dan ketekunana untuk mengahsilkan setiap kainkain batik yang berkualitas. Profesi ini tentu sangatlah penting, sama pentingnya dengan profesi lain seperti para pelukis, seorang guru, cendekiawan dan sebagainya. Perannya dalam menghasilkan batik betawi mulai dari nyorek yakni tahap awal yg dimulai dari membuat pola batik sesuai dengan motif budaya betawai, kemudian nyanting dengan cara menyoretkan malam batik ke atas kain dan memulai gambar-gambar garis di atas pola yang kosong dengan berbagai macam bentuk, lalu model yakni proses pencelupan kain yang sudah decanting ke cairan warna secara berulang-ulang, selanjutnta natar yakni proses menutupi bagian-bagian yang tidak memiliki warna. Tujuannya agar warna dasar pada pola tidak bercampur dengan warna yang diberikan setelah warna dasar. Kemudian melalukan tahap pewarnaan yakni kain batik yg sudah dinatar kembali diwarnai dengan warna yang lebih gelap dari warna dasar, untuk mendapatkan warna yang lebih pekat, lalu nyolet teknik pewarnaan yang ditujukan pada aera tertentu saja, mislanya untuk mewarnai daun, wajah atau bunga, terkahir ngolort yakni tahap akhir dimana malam yang ada dikain batik dibersihkan dengan cara merebus kain yang sudah selesai diwarnai ke dalam air mendidih. Ke tujug tahapan tersebut harus dilakukan dengan teliti dan hati-hati agar hasil batiknya berkualitas baik. Mereka para pembatik harus menguasai teknik-teknik dalam setiap langkah atau tahapan yang dilalui dalam hal membatik. 
b. Aktualisasi Diri

Aktualisasi diri sebagai "kekuatan diri" yang dimiliki setiap individu khususnya para pembatik. Hal ini berkaitan dengan perjalanan kehidupan seseorang untuk mendapatkan nilai luhur dari profesi pembatik. Untuk memutusakan menjadi seorang pembatik dalam perjalanannya mendapatkan nilai-nilai luhur dari profesi yang ditekuni (keterampilan menggambar, melukis). Ini bukan berarti mereka secara kebetulan menjadi pembatik, namun mereka menjalaninya sejak lama dan berniat untuk menekuni profesi tersebut. Pembatik merupakan bagian dari dirinya yang mengantarkan mereka menjadi bagian dari individu-individu yang berkontribusi dalam melestarikan salah satu budaya Indonesia yakni batik Betawi.

Mereka memilih profesi pembatik sebagai “aktualisasi diri' dikarenakan umumnya mereka adalah ibu rumha tangga dan remaja yang tidak melanjutkan pendidikan ke perguruan tinggi sehingga dengan menekuni profesi pembatik mereka bisa bertemu dengan orang-orang yang samasama memiliki hobi dan profesi yang sama. Profesi pembatik merupakan profesi yang memiliki nilai-nilai penting, karena melalui karya-karya mereka Batik Betawi hingga saat ini terus dilestarikan.

c. Dukungan Keluarga

Pengungkapan latarbelakang memilih profesi pembatik dimaknai sebagai "dukungan keluarga". Pembatik memiliki rasa kepercayaan diri yang kuat dan kemauan untuk terus belajar mengembangkan kemampuanya dalam hal membatik, membuatnya di mata keluarga khususnya kepada orang tua, suami dan anak-anaknya memiliki kelebihan, keunikan dan keistimewaan pada psikologi diri seperti sabar, berani dan suka berkomunikasi dengan orang lain. Psikologi diri dimiliki muncul pada saat melakukan tindakan komunikasi dengan orang lain sebagai komunikasi verbal dan nonverbal.

Dalam kaitannya dengan psikologi komunikasi, seseorang/individu ketika memperoleh dukungan dengan orang-orang yang secara emosional memiliki hubungan yang dekat maka akan berdampak pada komunikasi diantara orang-orang tersebut. Keterbukaan diri dan komunikasi yang efektif diantara pembatik dan lingkungan keluarganya akan berdampak prositif dalam meningkatkans semangat belajar dan semangat kerja yang dimiliki oleh seorang pembatik. Hal ini tentu sangat penting mengingat profesi sebagai pembatik dibutuhkan orang-orang yang memiliki kepribadian tenang dan sabar dalam bekerja.

d. Kegiatan Tambahan

Latar belakang setiap individu yang memutuskan untuk menekuni profesi pembatik juga disebabkan oleh kurangnya aktivitas lain yang dilakukan. Hal ini dikarenakan dominan mereka yang berprofesi 
pembatik di Sercai Batik Betawi adalah ibu rumah tangga dan juga para remaja yang tidak melanjutkan pendidikannya ke tingkat SMA maupun Universitas. Profesi pembatik dijadikan sebagai ladang utama untuk bisa melakukan aktivitas selain hanya berada dirumah. Melalui aktivitas membatik, para pembatik tidak hanya belajar menggambar dan membuat batik tetapi juga bersosialsiasi dengan para pembatik lainnya. Intekasi dan komunikasi yang terjadi di seraci Batik Betawi menunjukkan sikap kekeluargaan yang harmonis dan saling mendukung untuk mengahsilkan karya-karya batik yang baik dan dapat diterima dipasaran. Mengacu pada pembahasan di atas, maka motif memilih profesi pembatik dapat dirangkum menjadi sebuah bagan sebagai berikut :

\section{Gambar 1.1 Motif Sebab Menjadi Pembatik}

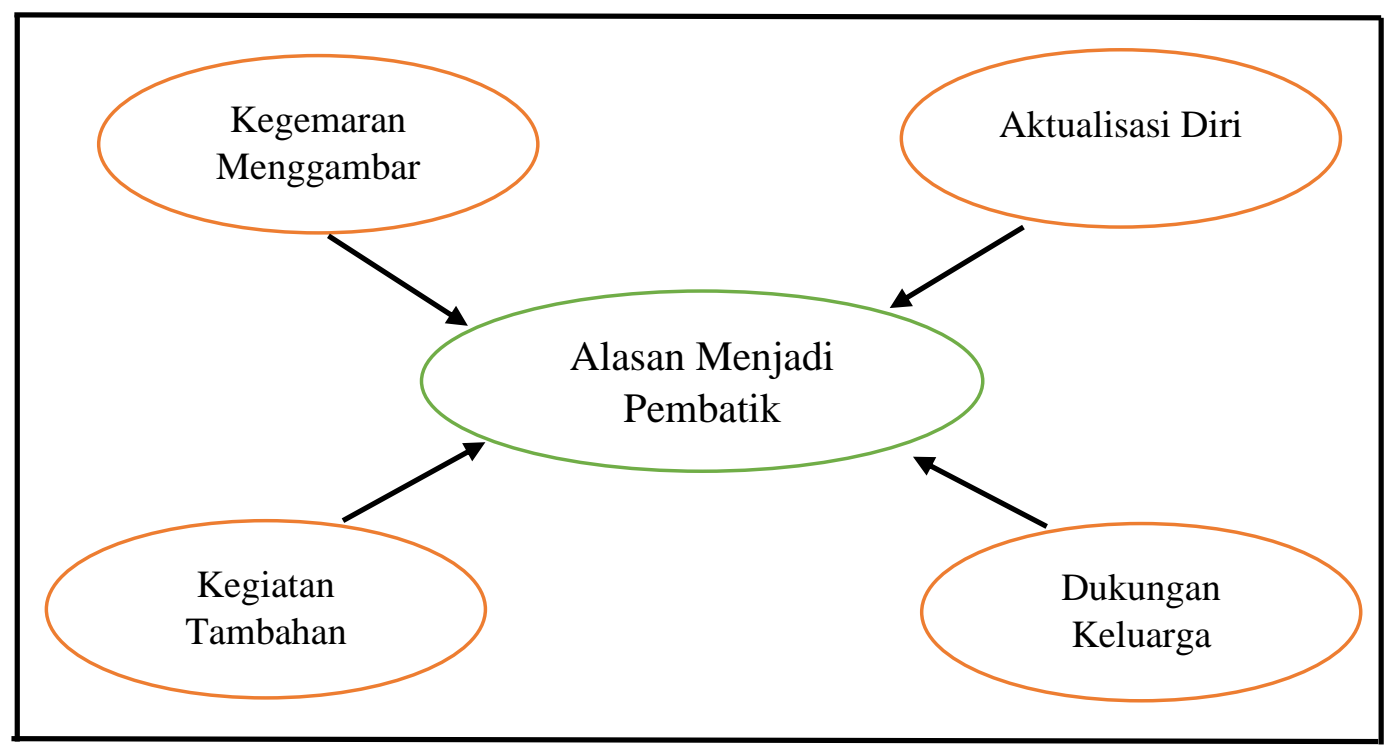

Sumber: Hasil Penelitian, 2018

Motif yang melatarbelakangi individu saat memutusakan untuk memilih profesi pembatik di Seraci Batik Betawi dikategorikan sebagai because motive. Pengakategorian motif ini merujuk pada identitas diri yang berasal dari pengalaman komunikasi pembatik baik didalam lingkungan keluarga, tempat kerja dan lingkungan sosial.

\section{Motif Tujuan Memilih Profesi Pembatik}

Motif tujuan teridentifikasi yang mendorong individu atau orang-orang melakukan tindakan komunikasi dengan memilih profesi pembatik untuk mendapatkan manfaat cukup beragam. Keberagaman motif tujuan tersebut dilatarbelakangi dari berbagai aspek pengalaman komunikasi yang mengkontruksi diri mereka untuk memilih profesi pembatik. 
a. Melestarikan Batik Betawi

"Cinta Tanah Air". Memaknai batik sebagai warisan budaya Indonesia yang pantas untuk di abadikan. Bagi pembatik di Seraci Batik Betawi, memilih profesi pembatik menjadikan mereka sebagai generasi bangsa yang berusaha melestarikan Batik Betwai melalui karya-karya batik yang dihasilkan. Keterlibatan pembatik dalam melestarikan batik Betawi patut di apresiasi sebab melalui karya-karya mereka sampai saat ini masyarakat mampu menikmati keindahan disetiap kain batik betawi. Melalui pelestarikan batik betawi diharapkan mampu mengedukasi generasi muda akan pentingnya mempertahankan produk budaya Indonesia yakni Batik. Bagi pembatik di seraci Betawi, dengan memilih profesi sebagai pembatik secara tidak langsung mereka ikut serta berkontribusi dalam menjaga dan melestarikan salah satu asset budaya Indonesia yakni batik Betawi.

Dalam perkembangannya, batik yang dijadikan sebagai produk budaya Indonesia sangat erat kaitannya dengan pertahanan negara Indonesia itu sendiri. Keterkaitan antara batik dan ketahanan nasional dapat diartikan bahwa batik sebagai perekat ketahanan dan jati diri kebudayaan bangsa. Tidak bisa dipungkiri bahwa posisi batik sebagai salah satu identitas bangsa semakin diperkuat sehingga berdampak pada menguatnya daya saing serta daya tahan budaya bangsa.

b. Sebagai Promosi Batik

"Media Promosi". Keberadaan batik betawi memiliki peranan penting dalam menjaga dan melestarikan budaya Betawi itu sendiri. Melalui seni membatik, para pembatik berharap generasi-generasi muda menganggap penting keberadaan batik khususnya batik betawi itu sendiri. Memilih untuk menekuni profesi Batik bukan terjadi begitu saja, tetapi para pembatik memiliki tekad untuk terus mempromosikan batik Betawi ke masyarakat luas melalui hasil karya batiknya.

c. Bangga

Para pembatik di kelompok seraci batik Betawi memiki rasa kebanggaran tersendiri terhadap profesi yang ditekuni. Interkasi dan komunikasi yang dijalin sesama pembatik (pekerja seni) terdapat rasa kepuasaan emosional yang dirasakan oleh pembatik itu sendiri ketika menyaksikan hsil karnyanya digunakan oleh orang lain. Inilah yang mereka sebut menjadi pembatik memiki kebahagiaan hidup sendiri. Pengalaman diri memilih profesi pembatik, ditemukan kategori kebanggan memilih sebagai pembatik. Profesi ini memengaruhi kehidupannya dengan penghidupan yang lebih kreatif, dapat bersosialisasi dengan sesame pembatik dan masyarakat luas serta berimpikkasi pada psikologi diri menjadi individu yang percaya diri. Motif memilih profesi pembatik bertujuan agar dirinya memiliki 
kebanggan sebagai pembuat/pelukis batik, karena melalui kreatifitas membatiknya menjadikan batik Betawi lebih dikenal di masyarakat dan juga banyak yang menggunakan batik betawi sebagai fashion.

d. Menunjukkan Kemampuan

"Kemampuan pada orang lain" memiliki keahlian di bidang pembatik tentu menarik perhatian dikalangan masyarakat setempat. Apalagi mengingat mereka yang berprofesi sebagai pembatik di Seraci Batik Betwai tingkat pendidikan sebatas tamat SMP dan SMA. Hal inilah yang menjadi kesmepatakn pembatik untuk menunjukkan kemmampuannya dan mendapat mpengakuan dari masyarakat sekitar melalui hasil karya batik Betwai tersebut. Motif ingin menunjukkan kemampuan dan terlihat adanya kebanggan untuk dikatakan hanya bisa mengurus rumah tangga, tidak mampu bekerja. Mereka yang memilih profesi pembatik, melakoni pekerjaan ini sebagai tantangan untuk menghadapi anggapan individu lain bahwa mereka yang kurang menempuh pendidikan ke jenjang pergurusan tinggi tidak memiliki kemampuan. Ini yang menjadi kesempatan bagi pembatik di Seraci Batik Betawi utnuk menunjukkan kemampuan dan kreatifitasnya sehingga mereka mendapat pengakuan dilingkungan sosialnya.

e. Menambah Penghasilan

Para pembatik melakoni pekerjaannya bertujuan untuk membantu dan meringankan kehidupan keluarga. Mereka menjadi wanita kuat, mandiri dalam menjalan kehidupan sehari-harinya. Perjalnan hidup individu, bisa pembatik, ditandai adanya niat untuk tetap bekerja demi membantu meringankan perekonomian keluarga. Komitmen memiliki keberagaman memilih profesi pembatik, ada juga yang memiliki alasan untuk "menambah uang jajan".

Gambar 1.2 Motif Tujuan Menjadi Pembatik

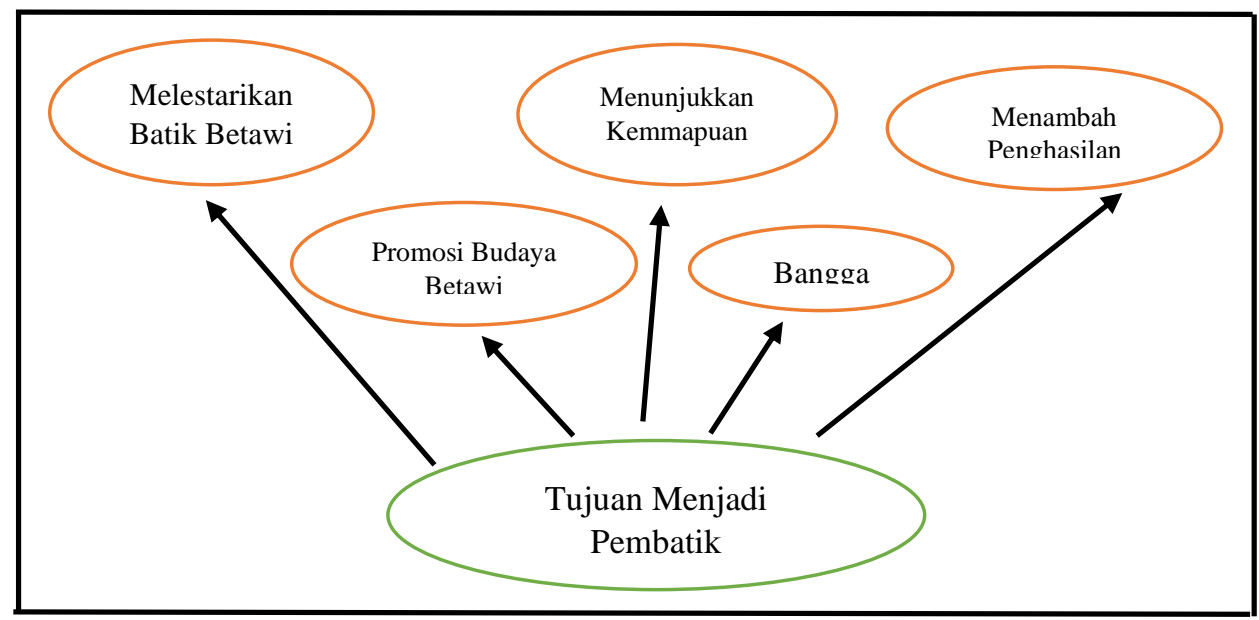

Sumber: Hasil Penelitian, 2018 
Motif setiap inidvidu dalam memilih menjadi pembatik tidak terbentuk begitu saja. Terdapat sejumlah interkasi dan komunikasi yang terkaumulasi menjadi satu pengalaman dan mengahsilkan penegatahuan yang akhirnya dimiliki oleh para pembatik. Pengalaman pun tidak serta merta ada didalam diri setiap individu. Pengetahuan dihasilkan oleh interkasi yang didalamnya melibatkan proses pembentukan motif dari dalam diri pembatik saat mereka memutuskan untuk menekuni profesi tersebut. Setiap pengetahuan dan pengalaman yang dimiliki individu menimbulkan ekspektasi untuk mewujudkan sutau aktivitas tertentu, yang dapat dikategorikan kedalam kelompok "motive in-order-to".

Schutz dalam Kusworno (2009:17) menghubungkan antara pengetahuan ilmiah dengan pengalaman sehari-hari dan dari kegiatan dimana pengalaman dan pengetahuan itu berasal (Kuswarno, 2009: 17). Setiap pengetahuan dan pengalaman sehari-hari akan berorientasi pada tindakan. Dalam hal ini pengetahuan dapat diperoleh dari pengalaman berbagai informasi dengan inidvidu lain. Pengetahuan inilah yang dapat mendorong munculnya motif didalam diri individu untuk melakukan sesuatu. Motif untuk jadi pembatik dilandasi oleh pengetahuan mengenai tujuan yang diperoleh apabali mereka menjadi pembatik.

Motif timbul karena didasari oleh sebuah keinginan untuk mendapatkan tujuan dari setiap tindakan yang dilakukan. Motif juga muncul disertai adanya harapan yang ingin dicapai oleh setiap individu dalam menyelesaikan suatu pekerjaan. Kecenderungan individu dalam mengambil tindakan memilih profesi pembatik daoat dilihat dari motif mereka miliki. Motif sebagai landasan bagi setiap individu untuk bertindak. Hal ini sejalan yang dikatakan oleh Schutz bahwa dalam menggambarkan tindakan setiap indvidu dapat dilihat dari tindakan "because of motive" artinya motif sebab yang merujuk pada masa lalu dan tindakan "in order to motive", motif tujuan. Dengan demikian, para pembatik di kelompok Seraci Batik Betawi memiliki motif alasan dan motif tujuan dalam ketika memilih menekuni profesi tersebut. Dengan mengamati setiap motifnta dapat diketahui kecenderungan mereka ketika memilih profesi pembatik Betawi.

\section{Kesimpulan}

Setiap individu yang memilih dan mengambil tindakan untuk menjadi pembatik di Sercai Batik Betawi dengan berbagai motif yang beragam. Beberapa hasil temuan menjelaskan bahwa makna individu memilih profesi pembatik dilatarbelakangi oleh motif sebab dan motif tujuan. Pembatik memilih profesinya dilatarbelakangi oleh pengalaman komunikasi dialami pada masa lalu sebagai kegemaran menggambar, aktualisasi diri, kegiatan tambahan dan adanya dukungan dari keluarga. Sedangkan motif tujuan pembatik memilih profesi tersebut dikarenakan adanya keinginan untuk meleastarikan batik betawi, mempromosikan budaya betawi, menunjukkan 
kemampuan, merasa bangga terhadap diri sendiri dan menambah penghasilan. Dengan demikian, dalam penelitian ini tindakan sosial banyak digunakan ketika mereka memilih profesi pembatik. Pembatik memaknai dirinya sendiri dibentuk dari pengalaman di masa lalu dan tujuan melakukan tindakan membatik.

\section{Saran}

Penelitian ini dapat dikembangkan lagi sebagai pengembangan keilmuan komunikasi terkait pembatik Betawi dengan metode berbeda seperti etnografi komunikasi. Selain itu, pelestraian budaya Betawi tidak hanya dapat dilakukan melalui promosi Batik Betawi tetapi dapat dilakukan dengan berbagai macam cara khusunya dalam mengenalkan budaya betawi (Batik Betwai) kepada generas-generasi muda. Terkahir diharapkan pemerintah setempat dapat memberikan perhatian lebih terdapat pengembangan diri para profesi batik, yang dapat dilakukan melalui pelatihan-pelatihan profesi batik guna meningkatkan kemampuan dan keterampilan pembatik. Sebab, kemajuan batik Betawi juga ditentukan oleh kerjasama dari segala pihak khususnya pemerintah setempat, lembaga swadasya masyarakat dan pemilik industri batik itu sendiri.

\section{Daftar Pustaka}

Creswell, John W. 1997. Qualitatice Inquiry and Research Design: Choosing Among Five Tradition. Sage. Thousand Oaks.

Denzin, N.K \& Lincoln, Y.S. 2009. Handbook of Qualitative Research. California. Age Publications.

Sutopo.H.B. 2002. Metode Penelitian Kualitatif. UNS. Press

Iskandar, Eny, K. 2017. Batik Sebagai Identitas Kultural Bangsa Indonesia di Era Globalisasi. Junral GEMA, THN XXX/52/Agustus 2016-Januari 2017. ISSN: 0215-3092.

Indonesia.gunadarma.ac.id, 2015. Diakses pada tanggal 4 Januari 2019.

Kuswarno, Engkus. 2009. Metodologi Penelitian Komunikasi: Fenomenologi, Konsepsi, Pedoman, dan Contoh Penelitiannya. Bandung : Widya Padjajaran.

Littlejohn, S \& Foss, K.A. 2005. Theories of Humas Communication. Singapore: Thomson \& Wadsworth.

Rakhmat, Jalaluddin. 2000. Metode Penelitian Komunikasi. Bandung: Remaja Rosdakarya.

Saifuddin. 2013. Pengantar Teori-Teori Sosial: Dari Fungsionalisme Hingga Postmodernisme. Jakarta: Pustaka Obor.

Sugyono. 2013. Metode Penelitian Kuantitatif. Bandung: Alfabeta.

Turner, Bryan S. 2012. Teori Sosial Dari Klasik sampai Postmodern. Yogyakarta: Pustaka Pelajar. 